\title{
Fungsi Tuturan Motivatif Guru dalam Pembelajaran di SMA
}

\author{
Fransisca Dike Desintya Dipta Sasmaya ${ }^{1}$, Imam Suyitno $^{1}$, Sunoto ${ }^{1}$ \\ ${ }^{1}$ Pendidikan Bahasa Indonesia-Universitas Negeri Malang
}

\begin{tabular}{l}
\hline \hline INFO ARTIKEL \\
\hline Riwayat Artikel: \\
Diterima: 08-01-2019 \\
Disetujui: $15-01-2019$ \\
\hline
\end{tabular}

\section{Kata kunci:}

motivational speech function; learning;

high school student;

fungsi tuturan motivatif;

pembelajaran,

siwa SMA

\begin{abstract}
ABSTRAK
Abstract: This research was aimed to describe the function of teacher's motivation speech in SMA Katolik Diponegoro Blitar. The function of speech is divided into three categories, those are the function of fact information exchange, function $\mathrm{f}$ emotion exchange, and function of convicing of affecting. These three functions appear when the teacher gives the motivation speech in learning process, especially on Bahasa subject. The existence of those functions in the teacher's motivation speech shows that in the learning process is not only focus on the material delivery, but also giving motivation from the teacher to students with purposed function.
\end{abstract}

\begin{abstract}
Abstrak: Penelitian ini bertujuan untuk mendeskripsikan tentang fungsi tuturan motivatif guru dalam pembelajaran di SMA Katolik Diponegoro Blitar. Fungsi tuturan ini terbagi menjadi tiga kategori, yakni fungsi tukar-menukar informasi faktual, fungsi tukar-menukar emosi, dan fungsi meyakinkan atau memengaruhi. Ketiga fungsi tersebut muncul pada saat guru tengah memberikan tuturan motivasi dalam pembelajaran, khususnya dalam pembelajaran bahasa Indonesia. Terdapatnya fungsifungsi dalam tuturan motivatif guru tersebut menandakan bahwa dalam pembelajaran guru tidak hanya berfokus pada pemberian materi saja, melainkan guru juga memberikan motivasi kepada peserta didik dengan fungsi atau tujuan tersendiri sesuai dengan apa yang dikehendaki guru tersebut.
\end{abstract}

\author{
Alamat Korespondensi: \\ Fransisca Dike Desintya Dipta Sasmaya \\ Pendidikan Bahasa Indonesia \\ Universitas Negeri Malang \\ Jalan Semarang 5 Malang \\ E-mail: dikedds@gmail.com
}

Pada saat berkomunikasi, manusia menggunakan bahasa untuk dapat saling belajar, saling berhubungan, dan saling mengungkapkan segala sesuatu yang ingin dikemukakannya kepada seseorang yang diajak berkomunikasi. Ketika berkomunikasi dengan orang lain, manusia tidak akan pernah lepas dari penggunaan komponen-komponen penting dalam pertuturan. Menurut Sirait (2008), bahasa sebagai alat komunikasi manusia dapat digunakan dalam bentuk lisan dan tulisan yang dalam proses penyampaiannya melibatkan tiga komponen penting, yaitu pihak yang berkomunikasi, informasi yang dikemukakan, dan alat komunikasi. Pihak yang berkomunikasi meliputi penutur dan mitra tutur, informasi yang dikemukakan meliputi tuturan yang memiliki maksud dan tujuan tertentu, dan alat komunikasi yang digunakan adalah bahasa. Dalam penggunaan bahasa, pemakai bahasa tidak hanya menyampaikan pesan, tetapi juga menanggapi aksi sehingga terjadi interaksi. Dengan interaksi itu terjadilah hubungan timbal-balik antarpemakai bahasa dan terciptalah hubungan sosial yang lebih akrab dengan penggunaan bahasa lisan (Wahyuni, 2016). Pada konteks pertuturan, bahasa lisan selalu digunakan untuk mengomunikasikan maksud dan tujuan penutur kepada mitra tutur. Cara manusia dalam menggunakan bahasa lisan untuk mengomunikasikan maksud dan tujuan disebut tindak tutur.

Tindak tutur adalah pengucapan kalimat yang digunakan untuk menyatakan suatu maksud penutur kepada mitra tutur agar dapat diketahui maksudnya (Kridalaksana, 1984). Pernyataan tersebut sejalan dengan pendapat (Tarigan, 1986) yang menyatakan bahwa setiap ujaran atau ucapan pasti mengandung maksud dan tujuan tertentu. Pada pertuturan, kedua pihak, yaitu penutur dan mitra tutur akan terlibat dalam suatu peristiwa berbahasa dengan orientasi pada suatu tujuan tertentu. Selain itu, pada saat bertutur kata sangat diperlukan prinsip kesopanan. Misalnya, bahasa yang santun akan terlihat pada tuturan direktif yang dilakukan pada saat kegiatan belajar mengajar, yakni melalui tuturan bertanya, dan memerintah. Tuturan memerintah merupakan tipologi tindak tutur menyuruh, meminta, berharap, memohon, mempersilakan, mengajak, memberikan nasihat, dan melarang (Prayitno, 2011). Tindak tutur merupakan peristiwa yang terjadi dengan melalui konsep pemikiran secara matang yang mengandung fungsi, maksud, dan tujuan tertentu serta akan menimbulkan suatu pengaruh terhadap mitra tutur. 
Fungsi tuturan dapat diartikan sebagai peran atau tujuan dari suatu tuturan. Tuturan yang dihasilkan oleh penutur tentu memiliki fungsi tersendiri bagi mitra tutur. Fungsi tuturan tersebut akan menjadi pemahaman baru bagi mitra tutur. Fungsi tuturan tidak terlepas dari adanya tindak tutur sebagai pusatnya. (Searle, 1969) mendeskripsikan tuturan berdasarkan pada fungsi tuturan itu sendiri. Fungsi yang dikemukakan oleh Searle tersebut diklasifikasikan atas enam fungsi, yaitu (1) tukarmenukar informasi faktual, (2) tukar-menukar informasi intelektual, (3) tukar-menukar emosi, (4) tukar-menukar sikap, (5) meyakinkan atau memengaruhi, dan (6) sosialisasi. Keenam fungsi tersebut memiliki peran masing-masing dalam setiap tuturan yang diujarkan oleh penutur kepada mitra tutur. Oleh karena itu, setiap tuturan akan selalu memiliki fungsi/tujuan tertentu, baik untuk penutur itu sendiri maupun untuk mitra tuturnya.

Dari berbagai macam peristiwa berbahasa yang terkait dengan tuturan terdapat satu peristiwa yang menarik dikaji secara pragmatik, yakni peristiwa berbahasa guru kepada peserta didik dalam pembelajaran di kelas. Guru merupakan salah satu komponen manusiawi yang penting dalam proses belajar mengajar yang sekaligus berperan aktif dalam usaha pembentukan sumber daya manusia (Sardiman, 2014). Guru memiliki peran utama dalam membentuk perkembangan peserta didik guna mewujudkan tujuan hidupnya secara maksimal dan menyeluruh (Mulyasa, 2013). Menurut (Suparlan, 2008), guru merupakan seorang manusia yang memiliki tugas untuk mencerdaskan kehidupan bangsa, baik secara spiritual dan emosional, intelektual, fisikal, maupun lainnya. Menjadi seorang guru tidaklah mudah. Pada pembelajaran di kelas, guru tidak hanya memberikan materi saja, melainkan guru dituntut untuk dapat menuntun para peserta didiknya menuju keberhasilan dan kesuksesan dalam belajar. Tugas guru dalam menjalankan perannya sebagai seseorang yang profesional harus memiliki kompetensi untuk menciptakan siswa yang cerdas, berakhlak, dan terampil. Pada dasarnya fungsi dan tugas guru dalam pembelajaran adalah sebagai manager untuk mengarahkan kegiatan belajar siswa supaya dapat mencapai keberhasilan sesuai dengan apa yang diinginkan (Beatrik, 2016). Upaya-upaya guru dalam mencapai keberhasilan dan kesuksesan tersebut tidak lepas dari adanya proses pembimbingan hingga pada tahap penilaian. Hal ini sejalan dengan pendapat (Imran, 2010) yang mengatakan bahwa guru merupakan suatu jabatan atau profesi yang tentunya memerlukan keahlian khusus dalam tugas utamanya, yakni mendidik, mengajar, membimbing, mengarahkan, menilai, dan mengevaluasi setiap siswa dalam pendidikan formal. Selain memberikan ilmu pengetahuan, guru juga memiliki tugas untuk mengamalkan dan menanamkan nilai-nilai dan sikap pada peserta didik supaya mereka dapat memiliki kepribadian yang baik. Salah satunya adalah menerapkan kesantunan berbahasa. Kesantunan berbahasa dibutuhkan untuk membentuk kebiasaan bagi siswa dalam belajar membangun komunikasi yang berciri positif. Dalam proses membentuk kebiasaan tersebut, harus memberikan contoh bersikap santun, baik dalam berperilaku maupun dalam bertutur kata, supaya siswa dapat mencontoh dan mengambil sikap positif secara santun juga (Astuti, 2016). Kesantunan berbahasa apabila dilakukan dalam proses komunikasi akan menghindarkan konflik antara penutur dan mitra tutur, sehingga akan terjalin komunikasi yang harmonis antara keduanya (Chusnaini, 2015).

Pada proses pembelajaran, wacana guru yang diwujudkan melalui tuturan merupakan aspek utama yang sangat berpengaruh terhadap aktivitas belajar peserta didik. Wacana guru tersebut dapat memberikan efek pikiran, perilaku, dan pengalaman berbahasa bagi peserta didik. Menurut (Ibrahim, 1993), wacana guru dalam pembelajaran dicirikan oleh tindak tutur memberikan informasi, penjelasan, perintah, koreksi, definisi, dan bertanya. Hal tersebut sesuai dengan tugas seorang pendidik, yaitu mengarahkan peserta didik untuk dapat melakukan suatu tugas tertentu dalam pembelajaran. Dengan begitu, seorang guru akan menentukan mudah tidaknya materi tersebut dicapai oleh siswa. Fenomena tindak tutur yang terjadi dalam interaksi belajar mengajar tersebut tentunya berkaitan dengan aspek-aspek sosial dan budaya di lingkungan sekolah dan tindak tutur dalam berbahasa yang tidak semata-mata hanya menyangkut pilihan kosakata saja, melainkan juga menyangkut pada pemahaman peserta tutur dalam pembelajaran (Chandra, 2016). Akan tetapi, dalam pembelajaran guru tidak semata-mata hanya menugasi peserta didik untuk mendalami materi pembelajaran saja, melainkan guru juga harus memberikan dukungan kepada peserta didik melalui tuturan-tuturan yang dapat memotivasi peserta didik pada saat pembelajaran berlangsung untuk mencapai prestasi belajarnya.

Salah satu upaya yang dapat dilakukan guru dalam mengarahkan peserta didik agar menjadi lebih baik dalam belajar adalah dengan cara memberikan motivasi. Motivasi adalah suatu perubahan energi dalam diri seseorang yang ditandai dengan munculnya perasaan dan reaksi untuk mencapai suatu tujuan yang diinginkannya. Pernyataan tersebut sesuai dengan pendapat (Mulyasa, 2013) yang menyatakan bahwa motivasi akan memunculkan perubahan energi pada diri manusia, yaitu masalah kejiwaan, perasaan, dan emosi untuk kemudian bertindak sesuatu untuk mencapai tujuan yang diharapkannya. Pada pembelajaran di sekolah, peserta didik akan bersungguh-sungguh dalam belajar apabila memiliki motivasi tinggi yang tidak terlepas dari peran guru sebagai motivator. Keberhasilan peserta didik bergantung pada upaya guru dalam membangkitkan motivasi belajar dan upaya peserta didik itu sendiri dalam memaknai motivasi dari guru dan usaha pencapaiannya.

Motivasi belajar dapat hadir dari dalam diri siswa yang rajin membaca buku dan memiliki rasa ingin tahu yang tinggi terhadap suatu masalah (Hamdani, 2011). Guru memiliki berbagai cara untuk dapat memenuhi kompetensi yang telah ditentukan, salah satunya dengan memberikan penghargaan kepada peserta didik. Bentuk penghargaan tersebut adalah motivasi dalam bentuk pujian kepada peserta didik dengan tujuan untuk mengubah tingkah laku dan cara belajar siswa pada ranah kognitif, afektif, dan psikomotorik (Pratama, 2016). Motivasi tentu sangat penting dalam kegiatan belajar mengajar karena dapat mendorong semangat belajar peserta didik. Kurangnya motivasi akan memengaruhi semangat belajar peserta didik yang pada akhirnya dapat menyebabkan ketidakberhasilan peserta didik dalam mencapai tujuan yang maksimal. Motivasi belajar dapat diberikan di sekolah pada semua jenjang pendidikan, salah satunya pada jenjang SMA kelas X. Secara psikologis, peserta 
didik pada jenjang tersebut sudah memasuki taraf kedewasaan yang matang. Usia pada jenjang tersebut merupakan usia remaja yang mampu menggunakan kecerdasannya untuk bekerja, belajar, membayangkan, dan menggagas. Peserta didik pada jenjang SMA kelas X dapat dikatakan cara berpikirnya sudah secara formal. Oleh karena itu, motivasi yang diberikan oleh guru bukanlah hal yang sulit diterima dan dimaknai oleh peserta didik pada jenjang tersebut guna pencapaian tujuan belajar yang maksimal.

Terdapat dua penelitian sebelumnya yang relevan dengan penelitian ini. Pertama, (Arista, 2014) melakukan penelitian yang berjudul Tuturan Guru Bahasa Indonesia dalam Pembelajaran. Berdasarkan hasil penelitian yang telah dilakukan, diperoleh empat bentuk tuturan, dua strategi tuturan, dan sembilan pesan tuturan guru bahasa Indonesia dalam pembelajaran. Empat bentuk tuturan guru bahasa Indonesia dalam pembelajaran, yaitu bentuk tuturan representatif, direktif, komisif, dan ekspresif. Dua strategi yang digunakan guru dalam pembelajaran adalah strategi tindak tutur langsung dan strategi tindak tutur tidak langsung. Hasil penelitian yang terakhir adalah sembilan pesan tuturan guru, yaitu pesan perintah, permintaan, permohonan, ajakan, persilahan, memotivasi, larangan, harapan, dan anjuran. Kedua, (Bata, 2014) melakukan penelitian yang berjudul Tindak Tutur Pujian Guru dalam Interaksi Pembelajaran di SMK Yos Sudarso Ende. Berdasarkan hasil penelitian yang telah dilakukan, diperoleh tiga bentuk tindak tutur pujian guru, lima fungsi tindak tutur pujian guru, dan dua modus penyampaian tindak tutur pujian guru dalam interaksi pembelajaran. Tiga wujud tindak tutur pujian guru adalah kalimat imperatif, deklaratif, dan interogatif. Adapun lima fungsi tindak tutur pujian guru, yaitu fungsi memperhalus perintah guru, memperhalus teguran guru, memberi penguatan, memberi nasihat, dan fungsi penerimaan siswa terhadap guru. Hasil penelitian yang terakhir adalah dua modus penyampaian tindak tutur pujian guru yang terdiri atas modus tuturan langsung dan modus tuturan tidak langsung.

Tujuan penelitian ini mendeskripsikan fungsi tuturan motivatif guru dalam pembelajaran di SMA Katolik Diponegoro Blitar. Fungsi tersebut diklasifikasikan menjadi tiga kategori, yaitu (1) tukar-menukar informasi faktual, (2) tukar-menukar emosi, dan (3) meyakinkan. Masing-masing fungsi tersebut memiliki tujuan, yakni untuk mengidentifikasi, bertanya, melaporkan, dan mengatakan sesuatu (fungsi tukar-menukar informasi faktual), untuk menyatakan minat, rasa heran atau kagum, takut atau cemas, dan simpati (fungsi tukar-menukar emosi), dan untuk menyarankan, menyuruh, menasihati, dan memberi peringatan (fungsi meyakinkan atau memengaruhi).

\section{METODE}

Pendekatan penelitian ini adalah pendekatan kualitatif. Penelitian dengan pendekatan kualitatif bertujuan untuk menemukan pola hubungan yang bersifat interaktif, menemukan teori, menggambarkan realitas yang kompleks, dan memeroleh pemahaman makna (Sugiyono, 2015). Guna mencapai tujuan tersebut, proses pendekatan kualitatif melibatkan upaya-upaya penting, seperti mengajukan pertanyaan-pertanyaan dan prosedur-prosedur, mengumpulkan data yang spesifik dari para partisipan melalui perekaman, menganalisis data secara induktif, dan menafsirkan makna data (Creswell, 2009:4). Jenis penelitian ini adalah penelitian lapangan (field research). Tujuan penelitian ini adalah memecahkan masalah-masalah praktis dalam masyarakat (Mardalis, 1995). Secara khusus, penelitian ini akan membahas secara lengkap dan mendeskripsikan fungsi tuturan motivatif guru dalam pembelajaran di SMA Katolik Diponegoro Blitar.

Pada penelitian ini peneliti bertindak sebagai human instrument yang melakukan pengamatan mutlak karena data yang dikumpulkan bersifat alamiah dari tuturan guru dan bertindak pula sebagai pengumpul data. Peneliti sebagai pengamat partisipan/berperan serta dalam proses pengumpulan data (Moleong, 2002). Lokasi pada penelitian ini berada di SMA Katolik Diponegoro Blitar. Lokasi penelitian berada di Jalan Diponegoro Nomor 32, Kelurahan Bendogerit, Kecamatan Sananwetan, Kota Blitar. Pemilihan lokasi penelitian tersebut didasarkan pada tiga pertimbangan. Pertama, keterbukaan dan kesediaan sekolah untuk menjadi lokasi penelitian. Kedua, SMA Katolik Diponegoro Blitar termasuk sekolah yang belum pernah dilakukan penelitian tentang tuturan motivatif guru. Ketiga, pada observasi awal telah ditemukan tuturan motivatif guru yang diberikan secara merata dan berkelanjutan yang menjadikan siswa dapat termotivasi untuk belajar lebih giat, pengembangan diri, sikap, dan mental menjadi lebih baik.

Data penelitian ini berupa tuturan motivatif guru yang mencakup tentang fungsinya. Data tersebut merupakan tuturan lisan guru yang kemudian ditranskripkan ke dalam data tulis berupa kalimat yang mengandung motivasi. Data diperoleh dari hasil observasi saat proses pembelajaran berlangsung dengan menggunakan alat bantu rekam yang berupa handycam serta catatan lapangan. Sumber data penelitian ini adalah wacana kelas yang merujuk pada guru bahasa Indonesia kelas X SMA Katolik Diponegoro Blitar yang diambil secara natural dan terarah dalam bentuk rekaman video.

Pada penelitian ini, kegiatan yang dilakukan peneliti diawali dengan merencanakan penelitian, mengumpulkan data, mendeskripsikan, mengelompokkan, menyeleksi, menilai, mengecek data, dan menyimpulkan hasil penelitian. Pada kegiatan pengumpulan data, peneliti menggunakan instrumen yang dibantu dengan dua alat bantu, yaitu (1) lembar pencatatan observasi dan wawancara dan (2) alat perekam berupa handycam yang digunakan untuk merekam pada saat guru bertutur kata dalam proses pembelajaran. Instrumen tersebut didukung pula oleh tabel pemandu pengumpulan data dan tabel pemandu analisis data. Data yang sudah diseleksi ditranskripsi ke dalam tabel pemandu pengumpul data dan setelah itu dianalisis menggunakan bantuan tabel pemandu analisis data. Teknik pengumpulan data penelitian ini adalah teknik observasi dan teknik wawancara. 
Pada proses observasi dilakukan dua hal sebagai penunjang kegiatan observasi tersebut, yaitu pencatatan lapangan dan perekaman. Peneliti menggunakan tabel pemandu pengumpulan data sebagai alat pada proses pencatatan lapangan. Pencatatan lapangan dilakukan untuk mencatat sejumlah data tuturan yang tidak dimuat dalam rekaman audiovisual. Pencatatan lapangan diperlukan untuk mencatat sejumlah tuturan yang diperoleh dari guru sebagai sumber data. Selain pencatatan lapangan, peneliti juga menggunakan handycam sebagai alat perekaman. Perekaman dilakukan secara dominan saat guru tengah mengajar di dalam kelas. Kegiatan perekaman tersebut hanya menggunakan satu unit handycam. Rekaman yang dilakukan berupa rekaman audiovisual. Selanjutnya, teknik yang kedua adalah teknik wawancara yang dilakukan kepada guru Bahasa Indonesia kelas X untuk mengetahui maksud dan fungsi dari tuturan motivasi yang diberikan kepada peserta didik dalam pembelajaran yang dibantu dengan tabel pemandu wawancara. Penggunaan teknik wawancara ini berguna untuk mengetahui maksud dan fungsi tuturan guru yang dianggap peneliti belum mengetahui maksud dan tujuannya. Wawancara ini dilakukan secara temporal dan terbuka.

Analisis data penelitian ini melalui tiga tahap, yaitu (1) reduksi, (2) penyajian, dan (3) penarikan kesimpulan (Miles \& Huberman, 1992). Tahap pertama adalah tahap reduksi. Tahap reduksi dilakukan dengan empat cara, yaitu (1) melakukan proses transkripsi data tuturan primer ke dalam bentuk tulisan, (2) data yang telah ditranskrip kemudian diidentifikasi sesuai dengan fokus penelitian yang telah ditentukan, (3) melakukan proses pengklasifikasian berdasarkan fokus, yaitu bentuk, makna, dan fungsi tuturan, dan (4) melakukan penafsiran atau pemaknaan terhadap data yang sebelumnya telah diklasifikasi. Tahap kedua adalah penyajian. Tahap penyajian adalah tahap menyajikan data yang telah diklasifikasikan sebelumnya ke dalam bentuk tabel yang akan dipertanggungjawabkan dalam bentuk laporan. Tahap yang ketiga adalah tahap penarikan kesimpulan. Pada tahap terakhir ini peneliti melakukan proses verifikasi ulang terhadap data awal demi konsistensi data yang telah dikumpulkan, yakni data tentang fungsi tuturan motivatif guru dalam pembelajaran di SMA Katolik Diponegoro Blitar.

Pengecekan keabsahan temuan dilakukan dengan cara peningkatan ketekunan dan ketelitian dalam pengamatan. Menurut (Sugiyono, 2015), peningkatan ketekunan dan ketelitian dilakukan dengan cara melakukan pengamatan terhadap data secara lebih cermat dan berkesinambungan. Peningkatan ketekunan dan ketelitian dalam penelitian ini diawali dengan membaca berbagai referensi buku dan hasil penelitian yang terkait dengan temuan penelitian. Kemudian, dilanjutkan dengan melakukan pengamatan dan ketelitian secara mendalam terhadap data yang telah ditemukan. Temuan dalam penelitian ini adalah fungsi tuturan motivatif guru dalam pembelajaran di SMA Katolik Diponegoro Blitar yang dicermati secara mendalam dan menyeluruh agar diperoleh hasil yang akurat.

\section{HASIL DAN PEMBAHASAN}

Bab ini akan dipaparkan hasil penelitian dan pembahasan fungsi tuturan motivatif guru dalam pembelajaran di SMA Katolik Diponegoro Blitar yang diklasifikasikan menjadi tiga kategori fungsi tuturan, yaitu (1) tukar-menukar informasi faktual, (2) tukar-menukar emosi, dan (3) meyakinkan.

Fungsi tuturan dapat diartikan sebagai peran atau tujuan dari suatu tuturan. Tuturan yang dihasilkan oleh penutur tentu memiliki fungsi tersendiri bagi mitra tutur. Fungsi tuturan tersebut akan menjadi pemahaman baru bagi mitra tutur. Fungsi tuturan tidak terlepas dari adanya tindak tutur sebagai pusatnya. (Searle, 1969) mendeskripsikan tuturan berdasarkan pada fungsi tuturan itu sendiri. Fungsi yang dikemukakan oleh Searle tersebut diklasifikasikan atas enam fungsi. Akan tetapi, tidak semuanya terdapat datanya terkait dengan fungsi tuturan motivatif guru. Oleh karena itu, hanya ada tiga (3) kategori saja yang akan dipaparkan secara detail, yakni (1) tukar-menukar informasi faktual, (2) tukar-menukar emosi, dan (3) meyakinkan atau memengaruhi. Ketiga fungsi tersebut dijelaskan sebagai berikut.

1) Tukar-menukar Informasi Faktual

a. G : Cah, dalam menyelesaikan persoalan watak, kalian tidak boleh hanya menyebutkan tokoh itu baik dan yang antagonis yang jelek. Gak bisa. Kamu harus menyebutkan apa? Sifatnya. Baik itu seperti apa? Suka menolong, suka memberi, suka membantu, dan berbelas kasih. Gitu ya? Nah, yang tanda kutip jahat atau tidak baik harus disebutkan sifatnya.

M : Suka mencuri.

G : Suka mencuri, suka membuli, dan suka membohongi. Gitu ya? Paham ya? Oke. (DT 9)

DT9/SMAKDIPO/EKO/X/IPA1/CRPN/TIF/22-1-18

Konteks: Tuturan DT 9 diucapkan oleh seorang guru kepada peserta didiknya pada saat pembelajaran berlangsung di kelas X IPA 1 dengan materi teks cerpen. Penutur adalah guru bahasa Indonesia yang bernama Bapak Eko Hariyanto, sedangkan mitra tutur adalah peserta didik kelas X IPA 1. Tuturan tersebut menandakan bahwa G tengah memberikan motivasi kepada M untuk tidak secara langsung mengatakan sesuatu hal tanpa adanya bukti yang kuat. Pemberian motivasi ini bertujuan untuk menyebutkan bukti-bukti dari persoalan watak protagonis dan antagonis dalam materi teks cerpen yang diajarkan oleh G. Dengan menyebutkan bukti-bukti tersebut, diharapkan $M$ dapat memberikan paparan yang jelas dan tidak secara langsung mengatakan sesuatu tanpa adanya bukti yang kuat. Selain itu, dengan menyebutkan bukti-bukti tersebut, M juga dapat memilah dan memilih sifat mana yang dapat diterapkan dalam kehidupan sehari-hari. 
Data tuturan 1 (DT 9) merupakan data tuturan yang termasuk dalam fungsi tukar-menukar informasi faktual. Hal tersebut ditandai dengan kalimat yang isinya berfungsi untuk mengidentifikasi (menyebutkan). Data tuturan 1 (DT 9) memiliki fungsi untuk mengidentifikasi (menyebutkan) bukti-bukti dari persoalan watak protagonis dan antagonis dalam materi teks cerpen yang diajarkan oleh G kepada M. Dengan mengidentifikasi (menyebutkan) bukti-bukti tersebut, diharapkan M dapat memberikan paparan yang jelas dan tidak secara langsung mengatakan sesuatu tanpa adanya bukti yang kuat. Selain itu, dengan mengidentifikasi (menyebutkan) bukti-bukti tersebut, $\mathbf{M}$ juga dapat memilah dan memilih sifat mana yang dapat diterapkan dalam kehidupan sehari-hari.

b. G : Sama dengan teks yang lain, ada kebahasaan yang digunakan. Yang pertama untuk hikayat ini kebahasaan yang digunakan adalah menggunakan bahasa arkais. Bahasa arkais itu apa? Bahasa kuno. Bahasa kuno itu artinya ya kadangkadang bahasanya itu sulit dipahami, sulit untuk dimengerti. Kalau sekarang itu ada bahasa gaul. Contohnya apa bahasa gaul yang pernah kamu gunakan? (DT 37)

M : Kepo.

G : Kepo. Apa lagi?

M : Alay.

G : Alay, lebay, opo neh? Itu bahasa-bahasa gaul atau bahasa-bahasa sekarang, misalnya istilah-istilah dalam HP, internet, ada unggah, bluetooth, unduh. Ini bahasa tren tapi belum tentu bahasa yang kita pahami ini, gak tahu berapa puluh tahun lagi menjadi arkais, menjadi kuno bahasa itu.

DT37/SMAKDIPO/HAR/X/IPS2/HKYT/TIF/22-1-18

Konteks: Tuturan DT 37 diucapkan oleh seorang guru kepada peserta didiknya pada saat pembelajaran berlangsung di kelas X IPS 2 dengan materi teks hikayat. Penutur adalah guru bahasa Indonesia yang bernama Bapak Hariyadi, sedangkan mitra tutur adalah peserta didik kelas X IPS 2. Tuturan tersebut menandakan bahwa $G$ tengah memberikan motivasi kepada $M$ untuk dapat mengetahui serta memilah dan memilih bahasa-bahasa mana yang akan digunakan untuk berkomunikasi di zamannya. Pemberian motivasi ini bertujuan untuk menjelaskan kepada M supaya menggunakan bahasa-bahasa sesuai zamannya untuk berkomunikasi dengan satu sama lain. Hal ini dikarenakan apabila bahasa arkais/kuno yang digunakan untuk berkomunikasi, maka akan terjadi ketidakpahaman antara penutur dengan mitra tutur. Oleh karena itu, diharapkan $M$ dapat memilah dan memilih bahasa mana yang dapat diterapkan dalam kehidupan sehari-hari untuk berkomunikasi di zamannya sebelum bahasa tersebut menjadi kuno.

Data tuturan 2 (DT 37) merupakan data tuturan yang termasuk dalam fungsi tukar-menukar informasi faktual. Hal tersebut ditandai dengan kalimat yang isinya berfungsi untuk melaporkan dan mengatakan sesuatu. Data tuturan 2 (DT 37) memiliki fungsi untuk memberitahukan/melaporkan supaya $\mathbf{M}$ dapat mengetahui serta memilah dan memilih bahasa-bahasa mana yang akan digunakan untuk berkomunikasi di zamannya. Selain itu, G juga memberitahukan atau melaporkan sekaligus memotivasi $\mathrm{M}$ supaya dapat menggunakan bahasa-bahasa sesuai zamannya untuk berkomunikasi dengan satu sama lain. Hal ini dikarenakan apabila bahasa arkais/kuno yang digunakan untuk berkomunikasi, maka akan terjadi ketidakpahaman antara penutur dengan mitra tutur. Oleh karena itu, diharapkan $\mathrm{M}$ dapat memilah dan memilih bahasa mana yang dapat diterapkan dalam kehidupan sehari-hari untuk berkomunikasi di zamannya sebelum bahasa tersebut menjadi kuno.

c. G : Sama dengan teks yang lain, ada kebahasaan yang digunakan. Yang pertama untuk hikayat ini

kebahasaan yang digunakan adalah menggunakan bahasa arkais. Bahasa arkais itu apa? Bahasa kuno. Bahasa kuno itu artinya ya kadang-kadang bahasanya itu sulit dipahami, sulit untuk dimengerti. Kalau sekarang itu ada bahasa gaul. Contohnya apa bahasa gaul yang pernah kamu gunakan?

M : Kepo.

G : Kepo. Apa lagi?

M : Alay.

G : Alay, lebay, opo neh? Itu bahasa-bahasa gaul atau bahasa-bahasa sekarang, misalnya istilah-istilah dalam HP, internet, ada unggah, bluetooth, unduh. Ini bahasa tren tapi belum tentu bahasa yang kita pahami ini, gak tahu berapa puluh tahun lagi menjadi arkais, menjadi kuno bahasa itu. (DT 38)

DT38/SMAKDIPO/HAR/X/IPS2/HKYT/TIF/22-1-18

Konteks: $\quad$ Tuturan DT 38 diucapkan oleh seorang guru kepada peserta didiknya pada saat pembelajaran berlangsung di kelas X IPS 2 dengan materi teks hikayat. Penutur adalah guru bahasa Indonesia yang bernama Bapak Hariyadi, sedangkan mitra tutur adalah peserta didik kelas X IPS 2. Tuturan tersebut menandakan bahwa G tengah memberikan motivasi kepada $M$ untuk dapat mengetahui serta memilah dan memilih bahasa-bahasa mana yang akan digunakan untuk berkomunikasi di zamannya. Pemberian motivasi ini bertujuan untuk menyebutkan contoh-contoh penggunaan bahasa gaul pada eranya. Dengan menyebutkan contoh-contoh tersebut, diharapkan $M$ dapat memilah dan memilih bahasa mana yang dapat diterapkan dalam kehidupan sehari-hari untuk berkomunikasi di zamannya sebelum bahasa tersebut menjadi kuno. 
Data tuturan 3 (DT 38) merupakan data tuturan yang termasuk dalam fungsi tukar-menukar informasi faktual. Hal tersebut ditandai dengan kalimat yang isinya berfungsi untuk mengidentifikasi (menyebutkan). Data tuturan 3 (DT 38 ) memiliki fungsi untuk mengidentifikasi (menyebutkan) contoh-contoh bahasa gaul pada eranya kepada M. Dengan mengidentifikasi (menyebutkan) contoh-contoh tersebut, diharapkan $\mathrm{M}$ dapat memilah dan memilih bahasa mana yang dapat diterapkan dalam kehidupan sehari-hari untuk berkomunikasi di zamannya sebelum bahasa tersebut menjadi kuno.

Data-data yang telah dipaparkan tersebut telah ditinjau dan dianalisis secara mendalam terkait dengan fungsi tukarmenukar informasi faktual yang isinya berfungsi untuk mengidentifikasi (menyebutkan) dalam tuturan motivatif yang dituturkan oleh guru dalam pembelajaran. Seperti yang diungkapkan (Searle, 1969:36) bahwa mendeskripsikan tuturan itu berdasarkan pada fungsi tuturan itu sendiri. Fungsi fungsi tukar-menukar informasi faktual digunakan untuk mengidentifikasi, bertanya, melaporkan, dan mengatakan sesuatu.

2) Tukar-menukar Emosi

a. G : Ada yang bisa, alur maju itu yang seperti apa? Rio...

M : Alur maju itu dari awal dasar cerita menuju konflik lalu itu tidak ada cerita yang kembali ke masa lalu. Contoh, pada saat cerita mulai tokoh yang ada dalam cerita itu dapat kembali lagi, misalnya saya mengingat kalau saya perlu mengerjakan tugas lha ini alurnya bukan maju, sedangkan alur maju itu dalam cerita tersebut fakta lurus ke depan terus dan tidak ada cerita yang kembali.

G : Tepuk tangan untuk Rio. (DT 13)

M : (semua peserta didik bertepuk tangan untuk Rio)

DT13/SMAKDIPO/EKO/X/IPA1/CRPN/TME/22-1-18

Konteks: Tuturan DT 13 diucapkan oleh seorang guru kepada peserta didiknya pada saat pembelajaran berlangsung di kelas X IPA 1 dengan materi teks cerpen. Penutur adalah guru bahasa Indonesia yang bernama Bapak Eko Hariyanto, sedangkan mitra tutur adalah peserta didik kelas X IPA 1. Tuturan tersebut menandakan bahwa G tengah memberikan motivasi kepada M untuk memberikan pujian kepada salah satu peserta didik bernama Rio yang telah berhasil menjawab pertanyaan dari G. Pemberian motivasi ini bertujuan untuk memberikan pujian dan memberikan semangat kepada Rio yang telah berhasil menjawab pertanyaan dari G. Selain itu, motivasi yang diberikan $G$ kepada $M$ juga dapat menjadi ajang kompetisi yang sehat untuk mendorong peserta didik lainnya mendapatkan pujian dari $G$ dengan cara berani dalam menjawab pertanyaan dari $G$ (menghadapi tantangan).

Data tuturan 4 (DT 13) merupakan data tuturan yang termasuk dalam fungsi tukar-menukar emosi. Hal tersebut ditandai dengan adanya kata-kata pujian, yakni kalimat tepuk tangan untuk Rio dalam tuturan motivatif yang dituturkan oleh guru dalam pembelajaran Bahasa Indonesia tersebut. Kalimat tepuk tangan untuk Rio berfungsi untuk menyatakan suatu kekaguman dan penghargaan kepada seseorang atau suatu benda yang dianggap baik dan menyatakan pujian untuk membangkitkan rasa senang, baik untuk diri sendiri maupun orang lain. Dalam data tuturan 4 (DT 13), kalimat tepuk tangan untuk Rio memiliki fungsi untuk menunjukkan kekaguman G kepada salah satu peserta didik yang telah berhasil menjawab pertanyaan dari G. Selain itu, bukti kekaguman yang diberikan G melalui pujian dan motivasi kepada $M$ dapat menjadi ajang kompetisi yang sehat untuk mendorong peserta didik lainnya mendapatkan pujian dari $\mathrm{G}$ dengan cara berani dalam menjawab pertanyaan dari $\mathrm{G}$ (menghadapi tantangan).

b. G : Kita perhatikan pekerjaan temanmu. Tilang menjadi menilang. Benar?

M : Benar.

G : Tepuk tangan dong buat temanmu. (DT 53)

M : (semua peserta didik bertepuk tangan)

DT53/SMAKDIPO/EKO/X/BHS/MORF/TME/22-1-18

Konteks: Tuturan DT 53 diucapkan oleh seorang guru kepada peserta didiknya pada saat pembelajaran berlangsung di kelas X BAHASA dengan materi morfologi. Penutur adalah guru bahasa Indonesia yang bernama Bapak Eko Hariyanto, sedangkan mitra tutur adalah peserta didik kelas X BAHASA. Tuturan tersebut menandakan bahwa $G$ tengah memberikan motivasi kepada $M$ untuk memberikan pujian kepada salah satu peserta didik yang telah berhasil menjawab pertanyaan dari G. Pemberian motivasi ini bertujuan untuk memberikan pujian dan memberikan semangat kepada salah satu peserta didik yang berhasil menjawab pertanyaan dari G. Selain itu, motivasi yang diberikan G kepada M juga dapat menjadi ajang kompetisi yang sehat untuk mendorong peserta didik lainnya mendapatkan pujian dari $G$ dengan cara berani dalam menjawab pertanyaan dari $G$ (menghadapi tantangan).

Data tuturan 5 (DT 53) merupakan data tuturan yang termasuk dalam fungsi tukar-menukar emosi. Hal tersebut ditandai dengan adanya kata-kata pujian, yakni kata tepuk tangan dong dalam tuturan motivatif yang dituturkan oleh guru dalam pembelajaran Bahasa Indonesia tersebut. Kata tepuk tangan dong berfungsi untuk menyatakan suatu kekaguman dan penghargaan kepada seseorang atau suatu benda yang dianggap baik dan menyatakan pujian untuk membangkitkan rasa senang, 
baik untuk diri sendiri maupun orang lain. Dalam data tuturan 5 (DT 53), kata tepuk tangan dong memiliki fungsi untuk menunjukkan kekaguman $\mathrm{G}$ kepada salah satu peserta didik yang telah berhasil menjawab pertanyaan dari G. Selain memiliki makna tuturan memuji, data tuturan 5 (DT 53) juga mengandung motivasi dengan tujuan untuk memuji dan memberikan semangat kepada salah satu peserta didik yang berhasil menjawab pertanyaan dari G. Selain itu, bukti kekaguman yang diberikan $\mathrm{G}$ melalui pujian dan motivasi kepada $\mathrm{M}$ juga dapat menjadi ajang kompetisi yang sehat untuk mendorong peserta didik lainnya mendapatkan pujian dari G dengan cara berani dalam menjawab pertanyaan dari G (menghadapi tantangan).

c. G : Ada pertanyaan sampai di sini? Tidak? IPA 1 is the best memang. (DT 18)

M : Yeee...

G : Meskipun kamu adalah anak eksak yang mempelajari bagaimana nggawe bom sing diajari Pak Yudha di Kimia, tapi sastra juga memahami.

M : (semua peserta didik bertepuk tangan)

G : Tapi tetap cah, saya minta materi apapun yang diajarkan di kelas ini wajib kamu ikuti, termasuk materi cerpen ini wajib kamu kuasai. Kalau tidak ancamannya apa? Nilaimu yang tidak baik, tidak akan pernah ikut KKM. Betul?

M : Betul.

G : Kemarin Pak Eko bilang apa? Syaratmu naik yang pertama adalah punya catatan. Kenapa harus punya catatan? Karena dengan catatan itu modal dasar untuk bisa baik dalam belajar. Kan kalau mencatat itu berarti kerja tangan, ditambah kerja otak, dan yang kamu catat kemarin Pak Eko minta apakah satu buku? Tidak. Kalian bisa mengambil dari internet.

DT18/SMAKDIPO/EKO/X/IPA1/CRPN/TME/22-1-18

Konteks: $\quad$ Tuturan DT 18 diucapkan oleh seorang guru kepada peserta didiknya pada saat pembelajaran berlangsung di kelas X IPA 1 dengan materi teks cerpen. Penutur adalah guru bahasa Indonesia yang bernama Bapak Eko Hariyanto, sedangkan mitra tutur adalah peserta didik kelas X IPA 1. Tuturan tersebut menandakan bahwa G tengah memberikan motivasi kepada $M$ untuk menjadi seseorang yang hebat. Pemberian motivasi ini bertujuan untuk menyanjung $M$ dalam hal belajar karena menurut $G$ peserta didik kelas X IPA 1 telah memenuhi kriteria pembelajaran yang baik.

Data tuturan 6 (DT 18) merupakan data tuturan yang termasuk dalam fungsi tukar-menukar emosi. Hal tersebut ditandai dengan adanya kalimat pujian, yakni kalimat IPA 1 is the best dalam tuturan motivatif yang dituturkan oleh guru dalam pembelajaran Bahasa Indonesia tersebut. Kalimat IPA 1 is the best berfungsi untuk menyatakan suatu kekaguman dan penghargaan kepada seseorang atau suatu benda yang dianggap baik dan menyatakan pujian untuk membangkitkan rasa senang, baik untuk diri sendiri maupun orang lain. Dalam data tuturan 6 (DT 18), kalimat IPA 1 is the best memiliki fungsi untuk menunjukkan kekaguman G kepada peserta didik kelas X IPA 1 yang telah memenuhi kriteria pembelajaran yang baik. Selain itu, G juga memotivasi M supaya mau belajar dengan tekun dan bersemangat agar kelak akan menjadi seseorang hebat.

Data-data yang telah dipaparkan tersebut telah ditinjau dan dianalisis secara mendalam terkait dengan fungsi tukarmenukar emosi yang isinya berfungsi untuk memuji atau menyatakan suatu kekaguman sekaligus memberikan penghargaan melalui tuturan yang dituturkan oleh guru dalam pembelajaran. Seperti yang diungkapkan (Searle, 1969:36) bahwa mendeskripsikan tuturan itu berdasarkan pada fungsi tuturan itu sendiri. Fungsi fungsi tukar-menukar emosi digunakan untuk menyatakan minat, rasa heran atau kagum, takut atau cemas, dan simpati.

3) Meyakinkan/Memengaruhi

a. $\mathrm{G} \quad$ : Akan ulangan to?

M : Iya.

G : Kamu masuk IPA paling tidak kamu tahu arah. Arahmu masuk ke IPA itu nanti bagamana untuk dua tahun, tiga tahun mendatang. Makanya belajar. Nilai ini di semester satu menentukan untuk melanjutkan ke dunia perguruan tinggi sudah dihitung. Jadi, ayo belajar, belum terlambat. Coba diresapi kata-kata saya, semakin tinggi kelasnya, semakin dalam materinya, semakin sulit. Kalau kamu memilih IPA, ayo bagaimana Fisika, bagaimana Biologi, bagaimana Kimia, bagaimana Matematika. Ini pilihan. Ayo anak-anak mulai belajar. Tunjukkan kemampuanmu. Setiap pribadi pasti punya kelebihan, punya talenta, kembangkan kamu pasti mampu di bidang apa. Ayo belajar, belajar, dan belajar. Gunakan masa depanmu ini dengan sebaik-baiknya. Ayo, terutama Elier ini. Itu nanti akan membangun Papua. Lho sungguh anak-anak. Di sini disekolahkan supaya menjadi calon-calon pemimpin yang nanti menuju ke Papua itu merombak Papua menjadi begini (sambil mengacungkan jempol). Lha kamu juga jangan kalah. Kembangkan supaya kamu juga membangun negeri ini bagaimana. Lek iki cah (sambil menunjukkan seluruh anggota badan) ini nanti masuk ke ukuran satu musuh loro (1x2). Generasi penerusnya kamu ini. Indonesia mau kamu jadikan apa? Kamu ini yang punya untuk sepuluh tahun mendatang. Kamu yang akan memimpin. Maka dari itu, belajarlah. Harus itu. (DT 28) DT28/SMAKDIPO/MM/X/IPA2/HKYT/MYM/18-1-18

Konteks: $\quad$ Tuturan DT 28 diucapkan oleh seorang guru kepada peserta didiknya pada saat pembelajaran berlangsung di kelas X IPA 2 dengan materi teks hikayat. Penutur adalah guru bahasa Indonesia yang bernama Ibu Massa Mieke, sedangkan mitra tutur adalah peserta didik kelas X IPA 2. Tuturan tersebut menandakan bahwa G tengah memberikan motivasi kepada M untuk selalu belajar dan berusaha. Pemberian motivasi ini bertujuan untuk 
mengajak M supaya mau terus belajar dan mau menggunakan kemampuannya untuk meraih kesuksesan. G juga mengajak M untuk bisa menjadi seseorang yang hebat dan sukses bagi tanah kelahirannya kelak. Kesuksesan itu dapat diraih berkat usaha dan kemauan belajar yang tinggi. Oleh karena itu, G mengajak M untuk terus belajar agar sukses di masa depan.

Data tuturan 7 (DT 28) merupakan data tuturan yang termasuk dalam fungsi meyakinkan/memengaruhi. Hal tersebut ditandai dengan kalimat yang isinya berfungsi meyakinkan/memengaruhi mitra tuturnya agar melakukan tindakan yang disebutkan dalam tuturan si penutur dan untuk menimbulkan efek melalui tindakan si penyimak atau mitra tutur. Data tuturan 7 (DT 28) memiliki fungsi meyakinkan/memengaruhi murid/peserta didik (M) dengan cara memberi nasihat dan menyuruh untuk selalu belajar dan berusaha. Pada data tuturan 7 (DT 28), G juga memberi nasihat sekaligus memotivasi M supaya mau terus belajar dan mau menggunakan kemampuannya untuk meraih kesuksesan. Selain itu, G menyarankan M untuk dapat menjadi seseorang yang hebat dan sukses bagi tanah kelahirannya kelak. Kesuksesan itu dapat diraih berkat usaha dan kemauan belajar yang tinggi. Oleh karena itu, G senantiasa memotivasi M untuk terus belajar agar sukses di masa depan.

b. G : Pesan moralnya bagaimana? Kamu tidak boleh punya rasa malas untuk mengambil sesuatu yang jaraknya dekat, jangan menyuruh orang. Jangan menjadi remaja yang malas. Kalau kamu punya rasa malas di dalam pribadimu ini coba dihilangkan. Itu bisa dilatih anak-anak. Rasa malas itu bisa dihilangkan dengan latihan. Latihan dalam kehidupan seharihari. Dilatih bagaimana supaya tidak malas. Bagun pagi aduh $\mathrm{Bu}$, bar subuhan mbalik kemulan maneh. Tidak boleh ya, lebih baik belajar. Belajar pagi itu lebih bagus karena ini (sambil menunjuk kepala) masih fresh. (DT 32)

Konteks: Tuturan DT 32 diucapkan oleh seorang guru kepada peserta didiknya pada saat pembelajaran berlangsung di kelas X IPA 2 dengan materi teks hikayat. Penutur adalah guru bahasa Indonesia yang bernama Ibu Massa Mieke, sedangkan mitra tutur adalah peserta didik kelas X IPA 2. Tuturan tersebut menandakan bahwa G tengah memberikan motivasi kepada $M$ untuk tidak boleh memiliki rasa malas dalam diri masing-masing. Pemberian motivasi ini bertujuan untuk melarang $M$ supaya tidak malas dalam melakukan suatu hal. Jika rasa malas tidak dihilangkan, maka kesuksesan pun tidak akan pernah didapatkan. G menegaskan kepada M bahwa rasa malas ini dapat dihilangkan melalui proses di dalam kehidupan sehari-hari yang tentunya diiringi dengan niat yang kuat agar kesuksesan dan pribadi yang baik dapat tercapai.

Data tuturan 8 (DT 32) merupakan data tuturan yang termasuk dalam fungsi meyakinkan/memengaruhi. Hal tersebut ditandai dengan kalimat yang isinya berfungsi meyakinkan mitra tuturnya agar melakukan tindakan yang disebutkan dalam tuturan si penutur dan untuk menimbulkan efek melalui tindakan si penyimak atau mitra tutur. Data tuturan 8 (DT 32 ) memiliki fungsi meyakinkan peserta didik $(\mathrm{M})$ dengan cara memberi nasihat dan menyuruh untuk tidak memiliki rasa malas dalam diri masing-masing. Selain itu, data tuturan 8 (DT 32) juga mengandung motivasi dengan tujuan supaya M tidak malas dalam melakukan suatu hal. Jika rasa malas tidak dihilangkan, maka kesuksesan pun tidak akan pernah didapatkan. $G$ menegaskan kepada $\mathrm{M}$ bahwa rasa malas ini dapat dihilangkan melalui proses di dalam kehidupan sehari-hari yang tentunya diiringi dengan niat yang kuat agar kesuksesan dan pribadi yang baik dapat tercapai.

c. G : Jadi, ini pijakan terakhir sebutanmu menjadi siswa. Sejak kamu TK sampai sekarang semuanya itu siswa. Inilah tempat terakhir dan kamu harus sukses di tempat ini, sehingga nanti masuk menjadi jenjang mahasiswa minimal UM (Universitas Negeri Malang). Syukur-syukur kalau UB (Universitas Brawijaya), UGM (Universitas Gadjah Mada), dan UI (Universitas Indonesia) ini tembus. (DT 73)

M : Amin (serentak).

$\mathrm{G} \quad$ : Apa caramu? Allahuma Aamin. Ingin sukses to?

M : Iya, Pak.

DT73/SMAKDIPO/EKO/X/BHS/MORF/MYM/22-1-18

Konteks: Tuturan DT 73 diucapkan oleh seorang guru kepada peserta didiknya pada saat pembelajaran berlangsung di kelas X BAHASA dengan materi morfologi. Penutur adalah guru bahasa Indonesia yang bernama Bapak Eko Hariyanto, sedangkan mitra tutur adalah peserta didik kelas X BAHASA. Tuturan tersebut menandakan bahwa $G$ tengah memberikan motivasi kepada $M$ untuk bisa menembus jenjang perkuliahan di salah satu universitas ternama setelah lulus dari SMA. Pemberian motivasi ini bertujuan untuk menyarankan M supaya tidak bosan dalam belajar dan bisa melanjutkan ke jenjang perkuliahan. G menyarankan pula agar M bisa masuk di salah satu perguruan tinggi ternama di Indonesia.

Data tuturan 9 (DT 73) merupakan data tuturan yang termasuk dalam fungsi meyakinkan. Hal tersebut ditandai dengan kalimat yang isinya berfungsi meyakinkan/memengaruhi mitra tuturnya agar melakukan tindakan yang disebutkan dalam tuturan si penutur dan untuk menimbulkan efek melalui tindakan si penyimak atau mitra tutur. Data tuturan 9 (DT 73 ) memiliki fungsi meyakinkan peserta didik $(\mathrm{M})$ dengan cara memberikan nasihat dan menyuruh untuk bisa menembus jenjang perkuliahan di salah satu universitas ternama setelah lulus dari SMA. 
Selain itu, G juga menyuruh sekaligus memotivasi $M$ supaya tidak bosan dalam belajar dan bisa melanjutkan ke jenjang perkuliahan. $\mathrm{G}$ menyarankan pula agar $\mathrm{M}$ bisa masuk di salah satu perguruan tinggi ternama di Indonesia. Data-data yang telah dipaparkan tersebut telah ditinjau dan dianalisis secara mendalam terkait dengan meyakinkan atau memengaruhi yang isinya berfungsi untuk meyakinkan mitra tuturnya agar melakukan tindakan yang disebutkan atau yang dituturkan oleh guru dalam pembelajaran. Seperti yang diungkapkan (Searle, 1969) bahwa mendeskripsikan tuturan itu berdasarkan pada fungsi tuturan itu sendiri. Fungsi fungsi meyakinkan atau memengaruhi digunakan untuk untuk menyarankan, menyuruh, menasihati, dan memberi peringatan.

Semua fungsi tersebut mendukung gugus instruksional di dalam proses belajar mengajar dalam rangka terwujudnya perubahan tingkah laku belajar peserta didik. Wujud perubahan tingkah laku belajar peserta didik tersebut tampak pada peningkatan kualitas dan kuantitas kemampuan siswa dalam mengolah, merespon, dan mengombinasikan pesan instruksional (Abbas, 2003).

\section{SIMPULAN}

Penelitian ini telah menghasilkan bahasan mengenai fungsi tuturan motivatif guru dalam pembelajaran bahasa Indonesia di kelas X SMA Katolik Diponegoro Blitar. Fungsi tuturan tersebut terbagi menjadi tiga kategori, yakni (1) tukarmenukar informasi faktual, (2) tukar-menukar emosi, dan (3) meyakinkan. Masing-masing fungsi tersebut memiliki tujuan, yaitu pada fungsi tukar-menukar informasi faktual digunakan untuk mengidentifikasi, bertanya, melaporkan, dan mengatakan sesuatu, pada fungsi tukar-menukar emosi digunakan untuk menyatakan minat, rasa heran atau kagum, takut atau cemas, dan simpati, dan yang terakhir pada fungsi meyakinkan atau memengaruhi digunakan oleh guru untuk meyakinkan atau memengaruhi peserta didik agar dapat belajar dengan baik, menyelesaikan kewajibannya sebagai seorang pelajar dengan baik, membantu peserta didik mewujudkan cita-citanya hingga meraih kesuksesan, dan menjadi pribadi yang baik, baik di lingkup sekolah maupun di lingkup masyarakat.

Berdasarkan hasil temuan dari penelitian tentang fungsi tuturan motivatif guru dalam pembelajaran di SMA Katolik Diponegoro Blitar ini, peneliti memberikan tiga (3) saran, yakni (1) bagi guru, (2) bagi peserta didik, dan (3) bagi peneliti lain. Pertama, saran bagi guru. Guru disarankan untuk memberikan tuturan motivatif yang memiliki fungsi sesuai apa yang diinginkan kepada peserta didik. Selain itu, pemberian motivasi khususnya dalam hal belajar lebih ditekankan kepada peserta didik. Hal ini berguna untuk menunjang, baik nilai maupun sikap siswa dalam mengikuti pembelajaran di sekolah. Tidak hanya di sekolah saja, guru dapat memberikan motivasi dalam lingkup sosial yang diharapkan dapat menjadikan peserta didik seseorang yang memiliki pemikiran dewasa, memiliki tingkat kemandirian yang baik, dan memiliki wawasan luas untuk meraih kesuksesan. Kedua, saran bagi peserta didik. Peserta didik disarankan untuk dapat mengambil, mencermati, dan memahami setiap tuturan yang dituturkan oleh guru. Selain itu, peserta didik juga harus bisa mengambil dan meresapi makna atau maksud dari tuturan guru tersebut. Peserta didik juga harus bisa memilah dan memilih maksud tuturan guru yang bagaimana yang akan ia lakukan demi meningkatkan kualitas pribadinya. Dengan begitu, peserta didik akan terbiasa dan terlatih/termotivasi untuk menjadi pribadi yang lebih baik di kemudian hari. Ketiga, saran bagi peneliti selanjutnya. Peneliti lain disarankan untuk melakukan penelitian lanjutan terkait dengan respon peserta didik saat guru memberikan motivasi pada saat pembelajaran di kelas. Selain itu, peneliti lain juga dapat lebih mengembangkan topik-topik secara lebih rinci dengan menguraikan jenis-jenis tuturan motivatif guru dalam pembelajaran.

\section{DAFTAR RUJUKAN}

Abbas, N. (2003). Tindak Tutur Direktif Guru SLTP Negeri 5 Biromaru dalam Interaksi. Tesis tidak diterbitkan. Universitas Negeri Malang, Malang.

Arista, H. D. (2014). Tuturan Guru Bahasa Indonesia dalam Pembelajaran. Tesis tidak diterbitkan. Universitas Negeri Malang, Malang.

Astuti, M. P. (2016). Kesantunan Tuturan Direktif dalam Interaksi Pembelajaran di SMA Negeri 1 Batu. Tesis tidak diterbitkan. Universitas Negeri Malang, Malang.

Bata, F. (2014). Tindak Tutur Pujian Guru dalam Interaksi Pembelajaran di SMK Yos Sudarso Ende. Tesis tidak diterbitkan. Universitas Negeri Malang, Malang.

Beatrik, R. (2016). Tuturan Guru dalam Interaksi Pembelajaran di SMP Negeri 1 Palipi Kabupaten Samosir Sumatera Utara. Tesis tidak diterbitkan. Universitas Negeri Malang, Malang.

Chandra, N. E. (2016). Tuturan Guru yang Merepresentasikan Pendidikan Karakter dalam Konteks Pembelajaran di Kelas. Disertasi tidak diterbitkan. Universitas Negeri Malang, Malang.

Chusnaini. (2015). Kesantunan Berbahasa dalam Diskusi Kelas Siswa SMP Negeri 17 Malang. Tesis tidak diterbitkan. Universitas Negeri Malang, Malang.

Creswell, J. W. (2009). Research Design: Pendekatan Kualitatif, Kuantitatif, dan Mixed. Terjemahan Achmad Fawaid. Yogyakarta: Pustaka Pelajar.

Hamdani. (2011). Strategi Belajar Mengajar. Bandung: CV Pustaka Setia.

Ibrahim, A. S. (1993). Kajian Tindak Tutur. Surabaya: Usaha Nasional. 
Imran, A. (2010). Belajar dan Pembelajaran. Jakarta: PT Dunia Pustaka.

Kridalaksana. (1984). Kamus Linguistik. Jakarta: Gramedia.

Mardalis. (1995). Metode Penelitian. Jakarta: Bumi Aksara.

Miles, M. B., \& Huberman, A. M. (1992). Analisis Data Kualitatif: Buku Sumber Tentang Metode-Metode Baru. Terjemahan R. Rohidi. Yogyakarta: Universitas Indonesia.

Moleong, L. J. (2002). Metodologi Penelitian Kualitatif. Bandung: PT Remaja Rosdakarya Offset.

Mulyasa, E. (2013). Menjadi Guru Profesional. Bandung: Remaja Rosdakarya.

Pratama, P. M. (2016). Tuturan Memuji oleh Guru Perempuan dalam Interaksi Pembelajaran Bahasa Indonesia. Tesis tidak diterbitkan. Universitas Negeri Malang, Malang.

Prayitno, H. J. (2011). Tindak Tutur Direktif Pejabat dalam Peristiwa Rapat Dinas: Kajian Sosiopragmatik Berperspektif Gender di Lingkungan Pemerintah Kota Surakarta. Disertasi tidak diterbitkan. Universitas Sebelas Maret, Surakarta.

Sardiman. (2014). Interaksi dan Motivasi Belajar Mengajar. Jakarta: PT Raja Grafindo Persada.

Sirait, C. B. (2008). The Power of Public Speaking. Jakarta: PT Gramedia Pustaka.

Sugiyono. (2015). Metode Penelitian Pendidikan: Pendekatan Kuantitatif, Kualitatif, dan R\&D. Bandung: Alfabeta.

Suparlan. (2008). Menjadi Guru Efektif. Jakarta: Hikayat Publishing.

Tarigan, H. G. (1986). Pengajaran Pragmatik. Bandung: Angkasa.

Wahyuni, S. (2016). Kesantunan Berbahasa Siswa dalam Wacana Diskusi Kelas. Disertasi tidak diterbitkan. Universitas Negeri Malang, Malang. 